Article

\title{
Design and Optimization of Flexible Polypyrrole/Bacterial Cellulose Conductive Nanocomposites Using Response Surface Methodology
}

\author{
Yasong Chen ${ }^{1,2}$, Fuying Wang ${ }^{3,4}$, Lipan Dong ${ }^{3,4}$, Zheng $\mathrm{Li}^{3,4, *}{ }^{3}$, Li Chen ${ }^{1,5}$, Xinhai He ${ }^{6}$, \\ Jixian Gong ${ }^{3,4}$, Jianfei Zhang ${ }^{3,4}$ and Qiujin $\mathrm{Li}^{3,4}$ \\ 1 School of Material Science and Engineering, Tianjin Polytechnic University, Tianjin 300387, China; \\ yasongchen@126.com (Y.C.); chenlis@tjpu.edu.cn (L.C.) \\ 2 School of Mathematical Science, Tianjin Polytechnic University, Tianjin 300387, China \\ 3 Key Laboratory of Advanced Textile Composites (Tianjin Polytechnic University), Ministry of Education, \\ Tianjin 300387, China; 15822955053@163.com (F.W.); 13072257279@163.com (L.D.); gongjixian@163.com (J.G.); \\ zhangjianfei1960@126.com (J.Z.); vicmaldini@126.com (Q.L.) \\ 4 School of Textile Science and Engineering, Tianjin Polytechnic University, Tianjin 300387, China \\ 5 School of Chemistry and Engineering, Tianjin University of Technology, Tianjin 300391, China \\ 6 School of Physical Science and Technology, Tianjin Polytechnic University, Tianjin 300387, China; \\ vmssci@163.com \\ * Correspondence: lizheng_nx@163.com; Tel.: +86-158-2204-4516
}

Received: 19 April 2019; Accepted: 21 May 2019; Published: 2 June 2019

check for updates

\begin{abstract}
Flexible conductive materials have greatly promoted the rapid development of intelligent and wearable textiles. This article reports the design of flexible polypyrrole/bacterial cellulose (PPy/BC) conductive nanocomposites by in situ chemical polymerization. Box-Behnken response surface methodology has been applied to optimize the process. The effects of the pyrrole amount, the molar ratio of $\mathrm{HCl}$ to pyrrole and polymerization time on conductivity were investigated. A flexible PPy/BC nanocomposite was obtained with an outstanding electrical conductivity as high as $7.34 \mathrm{~S} \mathrm{~cm}^{-1}$. Morphological, thermal stability and electrochemical properties of the nanocomposite were also studied. The flexible PPy/BC composite with a core-sheath structure exhibited higher thermal stability than pure cellulose, possessed a high areal capacitance of $1001.26 \mathrm{mF} \mathrm{cm}^{-2}$ at the discharge current density of $1 \mathrm{~mA} \mathrm{~cm}{ }^{-2}$, but its cycling stability could be further improved. The findings of this research demonstrate that the response surface methodology is one of the most effective approaches for optimizing the conditions of synthesis. It also indicates that the PPy/BC composite is a promising material for applications in intelligent and wearable textiles.
\end{abstract}

Keywords: bacterial cellulose; pyrrole; response surface methodology; flexible conductive material

\section{Introduction}

Intelligent textiles are revolutionary fabrics based on the concept of bionics that integrate computing, digital components and electronics through novel technologies into textiles for advanced functionalities [1,2]. More concern is necessary for the fabrication of intelligent and wearable devices as they act as a part of the outfit when in touch with the human body [3]. The last decade has witnessed a rapid increase of interest in different fields including health monitoring, wearable gadgets, therapeutic devices with demanding properties such as flexible, light-weight, washable, bendable and conductive [4]. The increasing development of intelligent and wearable textiles has benefited 
from a major breakthrough in emerging flexible and conductive materials, which enable a flexible combination of conductive materials and traditional non-conductive textiles.

Although conventional metal conductors possess high conductivity, they cannot meet the requirements of flexible electronic equipment for elastic stretching and bending of materials [5], such as supercapacitors, actuators, sensors. At present, electronically conducting polymers (EPCs) including polypyrrole (PPy), polythiophene (PTh) and polyaniline (PANI) are typically used to coat on cellulose substrates for composite materials. They have excellent conductivity, controllable synthesis process and mechanical flexibility [6-10]. Among the promising EPCs, PPy and its derivatives have received great attention due to their high conductivity, high energy density, good environmental stability and low toxicity [10-12]. Deposition of PPy on a fiber surface of fabrics and yarn, such as silk [13], cotton [14,15], polyester [16] and polyamide [17] has been widely investigated. These conductive materials were generally obtained through in situ oxidative polymerization of pyrrole in the presence of textiles [18].

Among polymer fibers, bacterial cellulose (BC) is one kind of attractive biomaterial that shows outstanding properties together with a completely biodegradable and biocompatible nature [19]. BC is an unbranched polysaccharide, comprising linear chains of $\beta-1,4$-glucopyranose residues produced by microorganisms belonging to Acetobacter xylinum [20]. It possesses high crystallinity, purity and higher flexibility than plant cellulose or other cellulose derivatives [21-24]. Its chemical structure with the presence of hydroxyl and ether groups provides an excellent hydrophilic matrix for nanoparticles incorporation [25]. There have been some reports in the literature about the in situ production of PPy nanoparticles on the BC surface [26-32]. However, due to the aggregation of PPy nanoparticles on BC fibers under un-optimized synthesis conditions, the electrical conductivities of the composites were relatively low $\left(2.1-6.8 \times 10^{-2} \mathrm{~S} \mathrm{~cm}^{-1}\right)$ [33], which limited their applications in emerging technologies. In general, many factors such as pyrrole amount, polymerization time, molar ratio of oxidant (or dopant) to pyrrole and temperature have direct effects on the conductivity of PPy/BC composite. To our best knowledge, no attempts have been made on process optimization and interactions of two different factors were rarely carried out.

Based on the classical method, in order to conduct such experiments, one needs to change one parameter at each time and maintain other parameters constant. A great number of experiments might be performed which spend lots of time and energy. In order to reduce the limitations of the classical method, collective optimization of all the effective parameters via an empirical design based on statistics could be employed in the optimization process, like RSM which stands for response surface methodology [34]. Box-Behnken response surface methodology is a powerful experimental design tool and has been used to optimize and understand the performance of complex systems [35-38]. This design reduces the number of experimental runs which saves time and money. It does not contain factor level combinations where the factors are all at their higher or lower levels, they may be useful in avoiding experiments under extreme conditions, for which unsatisfactory results may occur [39].

In this study, a kind of flexible and conductive nanocomposite was prepared by in situ chemical polymerization of pyrrole using bacterial cellulose as a three-dimensional template. Box-Behnken design (BBD) was applied for the RSM in the experimental design with three independent variables at three levels. The three independent variables considered in this study were pyrrole amount, the molar ratio of hydrochloric acid $(\mathrm{HCl})$ to pyrrole and polymerization time. The aim of the current research was to gain the synthesis conditions which were optimum for electrical conductivity through an analysis of impacts of three important factors of the operation. Moreover, thermal, electrochemical and morphological properties of the prepared PPy/BC composite were evaluated. We believe that our work would contribute to the progress in flexible and conductive materials. 


\section{Materials and Methods}

\subsection{Materials}

BC pellicles were supplied by Hainan Yide Food Co., Ltd., Haikou, China. Pyrrole was purchased from Shanghai Kefeng Industrial Co., Ltd., Shanghai, China. $\mathrm{HCl}$ and ferric chloride hexahydrate $\left(\mathrm{FeCl}_{3} \cdot 6 \mathrm{H}_{2} \mathrm{O}\right)$ were obtained from Tianjin Sailboat Chemical Reagent Technology Co., Ltd., Tianjin, China. All the chemical reagents were used as received without further purification.

\subsection{Preparation of PPy/BC Composite by in Situ Chemical Polymerization}

The preparation procedure of $\mathrm{PPy} / \mathrm{BC}$ composites by in situ chemical polymerization was described in the previous work $[19,28,40]$. In this paper, a kind of flexible conductive material was designed using BC fiber suspension as a template. Firstly, the BC membranes were purified by being washed in distilled water several times. Then, they were soaked with distilled water for $12 \mathrm{~h}$ to fully swell and gently wiped off any excess moisture on the surface by a clean gauze. In order to prepare $1000 \mathrm{~mL}$ $\mathrm{BC}$ fiber suspension, the $\mathrm{BC}$ membrane with a mass of $98.68 \mathrm{~g}$ was cut into small cubes, then broken and dispersed with JZPB-165J01 Soymilk Machine (Zhongshan Jinzheng Life Electric Appliance Co., Ltd., Zhongshan, China) for $5 \mathrm{~min}$. The fiber suspension was diluted into $1.5 \mathrm{mg} \mathrm{mL}^{-1}$ by adding some distilled water. The suspension $(50 \mathrm{~mL})$ was added into the solution of $\mathrm{HCl}(2 \mathrm{M})$ and a certain amount of ferric chloride $\left(\mathrm{FeCl}_{3}\right.$, the molar ratio of $\mathrm{FeCl}_{3}$ to pyrrole was fixed at 1.38). Subsequently, the mixture was sonicated for $15 \mathrm{~min}$ at a power of $100 \mathrm{~W}$, magnetic stirred for $15 \mathrm{~min}$ and cooled to $4{ }^{\circ} \mathrm{C}$; a certain amount of pyrrole monomer was added into the above mixture and kept stirring at $4{ }^{\circ} \mathrm{C}$ for some time to obtain PPy/BC composite slurry (the molar ratio of $\mathrm{FeCl}_{3}$ to pyrrole was fixed at 1.38). The slurry was vacuum filtered to form a film, which was then freezing dried at $-40{ }^{\circ} \mathrm{C}$ for $24 \mathrm{~h}$. Finally, the PPy/BC composite was finished.

\subsection{Box-Behnken Design}

In the analysis of multi-factor experiments, the regression relationship presents a curve or a curved surface between the test index and multiple test factors, called response surface methodology (RSM). In this paper, RSM was employed for optimization of process parameters of PPy/BC composites using software Design Expert v.8.0.5b. The Box-Behnken design (BBD) was applied for the RSM in the experimental design with three independent variables at three levels. The three independent variables considered in this study were pyrrole amount $\left(X_{1}\right)$, molar ratio of hydrochloric acid to pyrrole $\left(X_{2}\right)$ and polymerization time $\left(\mathrm{X}_{3}\right)$.

Due to the different standards of each variable, it was necessary to normalize them prior to the analysis of the regression. The levels of variables (low, medium and high) were recorded as $-1,0$, and +1 , respectively. A linear transformation was applied in order to code the actual variables $\left(X_{i}\right)$ shown in Equation (1).

$$
\mathrm{x}_{\mathrm{i}}=\frac{\mathrm{X}_{\mathrm{i}}-\left(\mathrm{X}_{\max }+\mathrm{X}_{\min }\right) / 2}{\left(\mathrm{X}_{\max }-\mathrm{X}_{\min }\right) / 2}
$$

where $x_{i}$ was the coded value of the variable, $X_{i}$ was the actual value of variable, $X_{\max }$ stood for the maximum actual value of the variable and $X_{\min }$ represented the minimum actual value of the variable. It was obvious that " $\left(X_{\max }+X_{\min }\right) / 2$ " referred to the actual value of $X_{i}$ at the center point and " $X_{\max }-X_{\min }$ " corresponded to the change of value. Table 1 presentes the experimental range and levels of independent variables of design and preparation PPy-BC nanocomposites.

The experimental levels for each variable were selected based on the results of preliminary experiments and references $[19,27,41]$. A total of 17 experimental runs with different combinations of three factors were carried out. A full quadratic model was fitted to correlate the relationship between independent variables and response value represented by Equation (2). 


$$
Y=\beta_{0}+\sum_{i=1}^{k} \beta_{i} X_{i}+\sum_{i=1}^{k} \beta_{i i} X_{i}^{2}+\sum_{i=1}^{k} \sum_{i<j}^{k} \beta_{i j} X_{i} X_{j}+\varepsilon
$$

where $Y$ was the response value of electrical conductivity, $X_{i}$ and $X_{j}$ were the value of independent variables ( $i$ and $j$ were used to index the range of the pattern from 1 to $k$ ), $k$ represented the number of independent variables $(\mathrm{k}=3), \beta_{0}$ was a constant, $\beta_{\mathrm{i}}$ stood for the linear coefficient, $\beta_{\mathrm{ii}}$ referred to the second order effect on regression coefficients, $\beta_{\mathrm{ij}}$ corresponded to the interaction coefficient, and $\varepsilon$ was the statistical error of the model [34]. The response value $Y$ was regarded as the comprehensive impact of the various factors. If the coefficient value before the item was more than zero, it indicated that the item would have a positive effect on response; if the coefficient value before the item was less than zero, the response value would decrease as the item increased.

Table 1. Experimental range and levels of independent variables.

\begin{tabular}{ccccc}
\hline \multirow{2}{*}{ Factors } & Labels & \multicolumn{3}{c}{ Levels } \\
\cline { 3 - 5 } & & $\mathbf{- 1}$ & $\mathbf{0}$ & $\mathbf{1}$ \\
\hline Pyrrole amount/mL & $\mathrm{X}_{1}$ & 0.1 & 0.3 & 0.5 \\
Molar ratio of HCl to pyrrole & $\mathrm{X}_{2}$ & 5 & 20 & 35 \\
Polymerization time/min & $\mathrm{X}_{3}$ & 60 & 180 & 300 \\
\hline
\end{tabular}

\subsection{Characterization and Electrical Measurements}

A double-electric measurement digital tester with four-point probe (ST2263, Suzhou Jingge Electronics Co., Ltd., Suzhou, China) was used to assess the square resistance of PPy/BC composite (with a size of $2 \mathrm{~cm} \times 2 \mathrm{~cm}$ ) at room temperature. Its thickness was averaged three times by Thickness Gauge (Taizhou Ai Test Instrument Co., Ltd, Taizhou, China.). And the conductivity could be calculated according to Equation (3).

$$
\mathrm{C}=1 /(\mathrm{R} \times \mathrm{d})
$$

where $\mathrm{C}\left(\mathrm{S} \mathrm{cm}{ }^{-1}\right), \mathrm{R}(\Omega), \mathrm{d}(\mathrm{cm})$ were the electrical conductivity, square resistance and thinness of the composite, respectively.

The morphology of the samples was characterized by field emission scanning electron microscope (FE-SEM, Hitachi S-4800, Tokyo, Japan).

The FT-IR spectra were recorded by Frontier Infrared Spectrometer (Thermo Fisher Scientific) over a wave number range from 420 to $4000 \mathrm{~cm}^{-1}$.

A thermos gravimetric analyzer was used to study its thermal stability with a heating rate of $10{ }^{\circ} \mathrm{C} \mathrm{min}^{-1}$ in a nitrogen atmosphere.

Cyclic voltammetry (CV), galvanostatic charge-discharge (GCD) and electrochemical impedance spectroscopy (EIS) were carried out at room temperature with CHI Electrochemical Analyzer/Work Station (Shanghai Chenhua Instrument Co., Ltd., Shanghai, China). A piece of PPy/BC composite (with a size of $1 \mathrm{~cm} \times 0.5 \mathrm{~cm}$ ) was immersed in $2.0 \mathrm{M} \mathrm{LiCl}$ electrolyte and used as the working electrode. No binders or other conductive materials were added. A titanium plate and an $\mathrm{Ag} / \mathrm{AgCl}$ were used as a counter electrode and a reference electrode, respectively. In the three-electrode system, CV and GCD were performed in the potential range from $-0.2 \mathrm{~V}$ to $0.6 \mathrm{~V}$. EIS was recorded in the frequency range from $0.01 \mathrm{~Hz}$ to $100 \mathrm{kHz}$ with an amplitude of $5 \mathrm{mV}$. The areal capacitance could be obtained by Equation (4) [42].

$$
\mathrm{C}_{\mathrm{S}}=\frac{\mathrm{I} \times \Delta \mathrm{t}}{\mathrm{S} \times \Delta \mathrm{V}}
$$

where $\mathrm{Cs}\left(\mathrm{F} \mathrm{cm}^{-2}\right), \mathrm{I}(\mathrm{A}), \Delta \mathrm{t}(\mathrm{s}), \mathrm{S}\left(\mathrm{cm}^{2}\right), \Delta \mathrm{V}(\mathrm{V})$ were the areal capacitance, the discharge current, the discharge time, area and the potential window, respectively. 


\section{Results and Discussion}

\subsection{Synthesis of PPy/BC Composite}

Figure 1 illustrates the fabrication process of PPy/BC composites. Firstly, the desired amount of $\mathrm{HCl}$ and $\mathrm{FeCl}_{3}$ solution was mixed with $\mathrm{BC}$ nanofibers suspension and ultrasonic cleaning for $15 \mathrm{~min}$ to ensure that it was mixed well. Then, the pyrrole monomer was added into the solution after the temperature was cooled down to $4{ }^{\circ} \mathrm{C}$. It was clear to see that the color of $\mathrm{BC}$ nanofibers suspension changed from white to black gradually due to polymerization of pyrrole in the presence of $\mathrm{FeCl}_{3}$. Finally, the mixture was vacuum filtered through a filtration membrane, followed by freeze-drying to gain the paper-like flexible PPy/BC composite. In contrast to the previous method [43], we intentionally omitted the elution steps for more $\mathrm{HCl}$ retention. The composites obtained exhibited the conductivities in the range from 2.52 to $7.81 \mathrm{~S} \mathrm{~cm}^{-1}$ (see Table 2 for details), which were much higher than those of $\mathrm{PPy} / \mathrm{BC}$ composites after being rinsed several times with deionized water (up to $2.26 \mathrm{~S} \mathrm{~cm}^{-1}$ ).

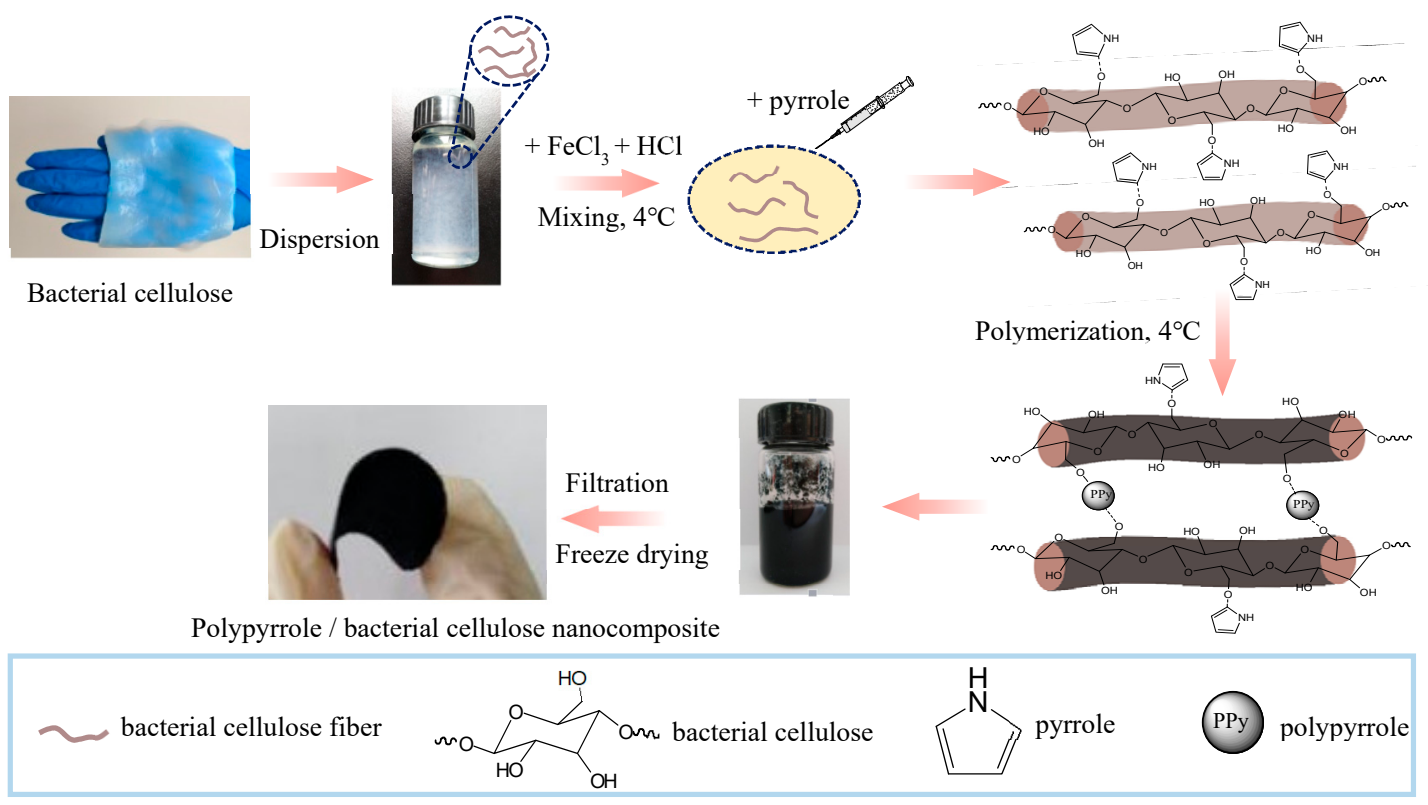

Figure 1. Schematic illustration of preparation PPy/BC nanocomposite.

Table 2. Response surface design matrix with experimental and predicted values.

\begin{tabular}{ccccccc}
\hline \multirow{2}{*}{ Run } & \multirow{2}{*}{$\mathbf{X}_{\mathbf{1}}$} & $\mathbf{X}_{\mathbf{2}}$ & \multirow{2}{*}{$\mathbf{X}_{\mathbf{3}}$} & \multicolumn{2}{c}{$\mathbf{Y}$ Conductivity/(S $\mathbf{~ c m}^{\mathbf{- 1}} \mathbf{)}$} & \multirow{2}{*}{ Error/(S $\mathbf{~ c m}^{\mathbf{- 1}} \mathbf{)}$} \\
& & & & Experimental & Predicted & \\
\hline 1 & 0 & 1 & -1 & 4.78 & 5.17 & -0.39 \\
2 & 0 & 0 & 0 & 6.93 & 7.14 & -0.21 \\
3 & 0 & 0 & 0 & 7.03 & 7.14 & -0.11 \\
4 & 1 & -1 & 0 & 3.08 & 3.20 & -0.12 \\
5 & -1 & 0 & -1 & 3.54 & 3.27 & 0.27 \\
6 & 0 & -1 & -1 & 5.48 & 5.16 & 0.32 \\
7 & -1 & 0 & 1 & 4.47 & 4.27 & 0.20 \\
8 & 1 & 1 & 0 & 4.71 & 4.12 & 0.59 \\
9 & 0 & -1 & 1 & 4.41 & 4.02 & 0.39 \\
10 & 0 & 0 & 0 & 7.08 & 7.14 & -0.06 \\
11 & -1 & -1 & 0 & 2.52 & 3.11 & -0.59 \\
12 & 0 & 0 & 0 & 6.87 & 7.14 & -0.27 \\
13 & 0 & 0 & 0 & 7.81 & 7.14 & 0.67 \\
14 & 1 & 0 & 1 & 2.86 & 3.13 & -0.27 \\
15 & 1 & 0 & -1 & 5.35 & 5.55 & -0.20 \\
16 & -1 & 1 & 0 & 3.18 & 3.06 & 0.12 \\
17 & 0 & 1 & 1 & 4.56 & 4.88 & -0.32 \\
\hline
\end{tabular}


Figure 2 describes the formation mechanism of PPy chain. $\mathrm{FeCl}_{3}$ acted as the oxidant creating chemically active cation-radicals of the monomers. The coupling between two radicals resulted in the formation of a bond between their $\alpha$-positions and the formation of dihydromer dication. The loss of two protons formed the aromatic dimer. Polymer chains continued to grow as long as pyrrole and $\mathrm{FeCl}_{3}$ were available [44]. PPy chain had a perfect ultra-long conjugated structure with $\mathrm{C}=\mathrm{C}$ bonds and $\mathrm{C}-\mathrm{C}$ bonds alternately arranged. If the molar ratio of $\mathrm{FeCl}_{3}$ to pyrrole was high, more counter anions would be left in the solution at the completion of the polymerization reaction. If the molar ratio of $\mathrm{FeCl}_{3}$ to pyrrole was low, the monomer may not be completely polymerized and conjugation lengths of PPy formed would be diminished [45]. The PPy chain was simultaneously doped by HCl during polymerization. The combination of the protons of the dopant and the carbon atoms on PPy backbone caused a reduction in the density of electron clouds on the carbon atoms for electrical conduction. The reaction mechanism of the formation of PPy was also discussed by Sadki et al. [46].

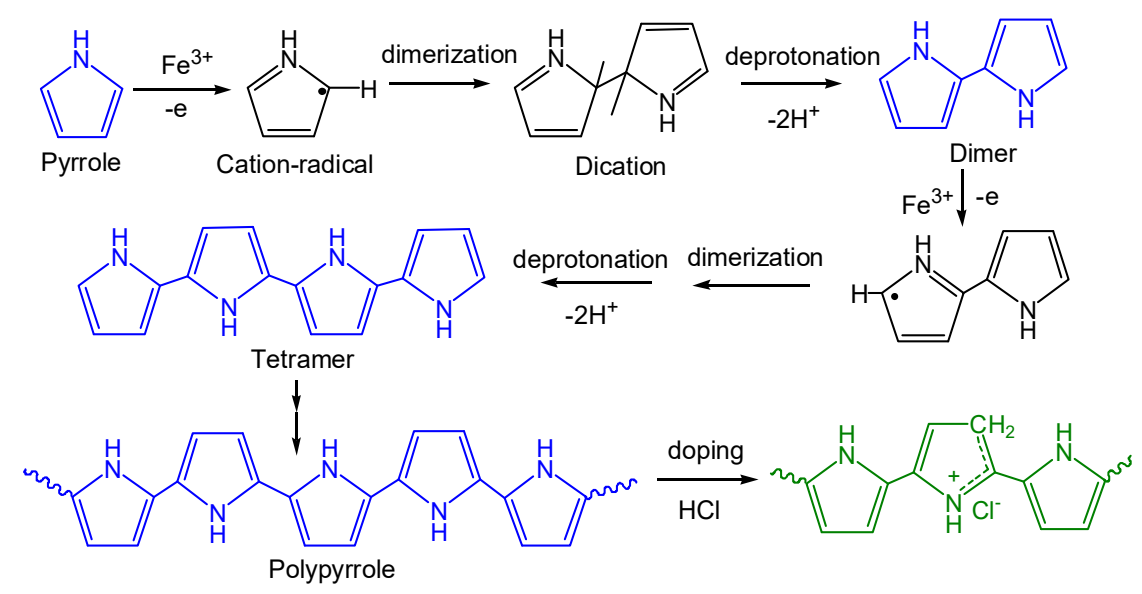

Figure 2. Schematic diagram of the polypyrrole formation mechanism.

Figure 3 presents the scanning electron microscope (SEM)micrographs of the pure $\mathrm{BC}$ membrane and $\mathrm{PPy} / \mathrm{BC}$ nanocomposite. The $\mathrm{BC}$ membrane consisted of continuous nanofibers with a diameter of about $60 \mathrm{~nm}$. A smooth surface morphology and three-dimensional porous network structure among the BC nanofibers could be clearly identified (Figure 3a). After polymerization, it was found that PPy nanoparticles deposited on the fiber surface connected to form a continuous nanosheath structure with a diameter of around $160 \mathrm{~nm}$ by taking along BC nanofibers (Figure $3 \mathrm{~b}$ ). The hydrogen bonds between imine groups of pyrrole and hydroxyl groups of $\mathrm{BC}$ might serve as a traction force to assist the growth of the continuous nanosheath of PPy over cellulose and avoid the large-scale aggregate formation $[47,48]$. This demonstrated that BC nanofiber could work as a good template for the polymerization of pyrrole for highly conductive composite [25].

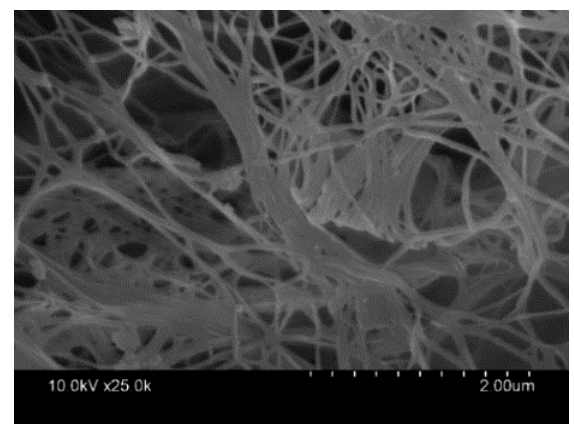

(a)

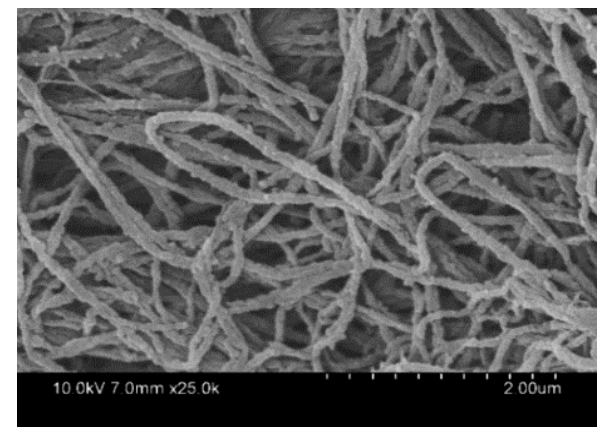

(b)

Figure 3. Scanning electron microscope (SEM) images of pure bacterial cellulose (BC) and PPy/BC composite: (a) pure BC membrane; (b) PPy/BC composite. 


\subsection{Response Surface Methodology Analysis}

A set of 17 experiments was run according to a $3^{3}$ Box-Behnken design. The results are shown in Table 2. The quadratic model in terms of coded factors for the response is presented in Equation (5). While a positive sign before a term showed a synergistic impact, a negative sign represented an antagonistic one [49].

$$
\mathrm{Y}=7.14+0.29 \mathrm{X}_{1}+0.22 \mathrm{X}_{2}-0.36 \mathrm{X}_{3}+0.24 \mathrm{X}_{1} \mathrm{X}_{2}-0.85 \mathrm{X}_{1} \mathrm{X}_{3}+0.21 \mathrm{X}_{2} \mathrm{X}_{3}-2.26 \mathrm{X}_{1}^{2}-1.15 \mathrm{X}_{2}^{2}-0.83 \mathrm{X}_{3}^{2} .
$$

Equation (4) indicates that the pyrrole amount, which had a coefficient of 0.29 , had the biggest positive linear impact among other parameters [34]. The interaction between pyrrole amount and polymerization time with a coefficient of 0.85 had the most negative impact on the conductivity of $\mathrm{PPy} / \mathrm{BC}$ composite.

The results of the second-order response surface model in the form of analysis of variance (ANOVA) are shown in Table 3. The statistical significance of the model equation was evaluated by F-values and $p$-values. The F-value and $p$-value of the model were 42.68 and 0.0007 , respectively, which explained the stability and significance of the model [50]. In the same way, $X_{1}, X_{2}, X_{3}, X_{1} X_{2}$, $X_{1} X_{3}, X_{2} X_{3}, X_{1}^{2}, X_{2}^{2}$ and $X_{3}^{2}$ were also reported. The decision coefficient $R^{2}$ explained the variability in the response values by the experimental parameters and their interactions [51]. $R^{2}$ was calculated to be 0.9543 , which implied $95.43 \%$ of the variation could be explained by this model and only $4.57 \%$ were not [52]. Adjusted $\mathrm{R}^{2}$, a measure of fit, was determined to be 0.8955 . The difference between decision coefficient $R^{2}$ and adj- $R^{2}$ was logically acceptable $[53,54]$. Both $R^{2}$ and adj- $R^{2}$ were higher than 0.80 , which suggested that the model had a high efficiency for the representation of the experimental data [55]. The non-significant value of lack of fit (more than 0.05) showed that the quadratic model was valid for the present study $[56,57]$. Thus, this model was suitable for determining the optimum condition of the $\mathrm{PPy} / \mathrm{BC}$ nanocomposites preparation.

Table 3. Analysis of variance (ANOVA) of response surface quadratic model.

\begin{tabular}{|c|c|c|c|c|c|c|}
\hline Source & Sum of Squares & Degree of Freedom & Mean Square & F-Value & $p$-Value Prob $>$ F & Significance \\
\hline Model & 42.68 & 9 & 4.74 & 16.23 & 0.0007 & $* *$ \\
\hline $\mathrm{X}_{1}$ & 0.66 & 1 & 0.66 & 2.24 & 0.1779 & \\
\hline$x_{2}$ & 0.38 & 1 & 0.38 & 1.3 & 0.2925 & \\
\hline$x_{3}$ & 1.02 & 1 & 1.02 & 3.47 & 0.1046 & \\
\hline $\mathrm{X}_{1} \mathrm{X}_{2}$ & 0.24 & 1 & 0.24 & 0.81 & 0.3994 & \\
\hline$x_{1} x_{3}$ & 2.92 & 1 & 2.92 & 10.01 & 0.0159 & * \\
\hline $\mathrm{X}_{2} \mathrm{X}_{3}$ & 0.18 & 1 & 0.18 & 0.62 & 0.4575 & \\
\hline$X_{1}^{2}$ & 21.54 & 1 & 21.54 & 73.73 & $<0.0001$ & $* *$ \\
\hline$X_{2}^{1}$ & 9.59 & 1 & 9.59 & 32.83 & 0.0007 & $* *$ \\
\hline$x_{3}^{2}$ & 2.88 & 1 & 2.88 & 9.86 & 0.0164 & * \\
\hline Residual & 2.05 & 7 & 0.29 & & & \\
\hline Lack of Fit & 1.46 & 3 & 0.49 & 3.36 & 0.1363 & \\
\hline Pure Error & 0.58 & 4 & 0.15 & & & \\
\hline Cor Total & 44.73 & 16 & & & & \\
\hline
\end{tabular}

Note: values of "Prob > F" less than 0.0500 indicated model terms were significant $\left(^{*}\right)$ and less than 0.0100 were extremely significant $\left.{ }^{* *}\right)$.

\subsubsection{Effect of Pyrrole Amount and Molar Ratio $\mathrm{HCl}$ to Pyrrole on Conductivity}

The response surface plot for electrical conductivity of PPy/BC nanocomposites for pyrrole amounts ranging from $0.1 \mathrm{~mL}$ to $0.5 \mathrm{~mL}$ and the molar ratio of $\mathrm{HCl}$ to pyrrole ranging from 5 to 35 against polymerization time of $180 \mathrm{~min}$ is shown in Figure 4a. The electrical conductivity initially increased and then decreased with a further increase in pyrrole amount. This was mainly due to more PPy formation at higher monomer concentration, but too much pyrrole might cause circuit blockage to affect electron conduction. As the molar ratio of $\mathrm{HCl}$ to pyrrole increased, conductivity initially 
decreased and then increased. $\mathrm{HCl}$ functioned as the dopant causing defects in PPy backbone and leading to the decrease of electron cloud density. With a further increase in dopant, there might be a reduction in intermolecular hopping of charge carriers due to an increased gap between the polymer chains by bulky side groups of the anions and thereby adversely affecting conductivity [58]. The drop might reflect that the detachment of PPy from the BC surface had occurred [59].

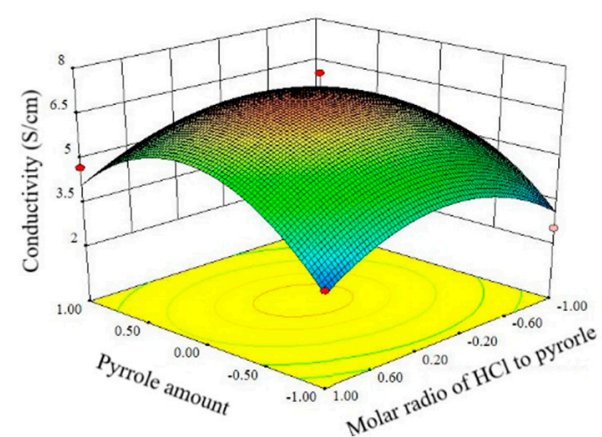

(a)

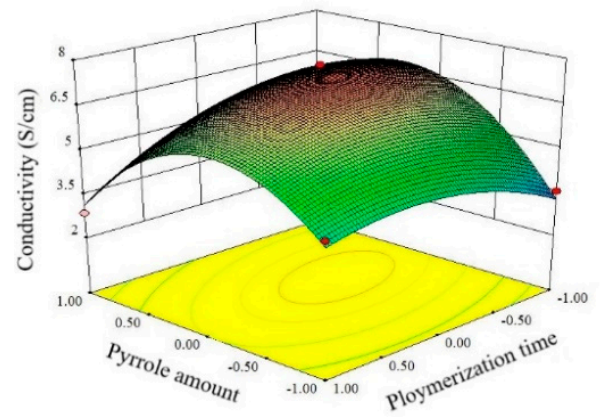

(b)

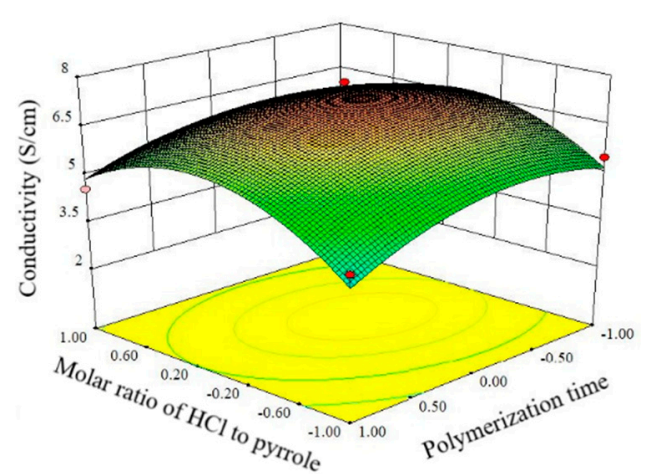

(c)

Figure 4. Response surface plots of independent variables on the conductivity of PPy/BC composite: (a) pyrrole amount and the molar ratio of $\mathrm{HCl}$ to pyrrole; (b) pyrrole amount and polymerization time; (c) molar ratio of $\mathrm{HCl}$ to pyrrole and polymerization time.

\subsubsection{Effect of Pyrrole Amount and Polymerization Time on Conductivity}

The response surface plot for electrical conductivity of PPy/BC nanocomposites for pyrrole amount ranging from $0.1 \mathrm{~mL}$ to $0.5 \mathrm{~mL}$ and polymerization time ranging from $60 \mathrm{~min}$ to 300 min against the molar ratio of $\mathrm{HCl}$ to pyrrole of 20 is shown in Figure $4 \mathrm{~b}$. It could be seen clearly that with the increase pyrrole amount the conductivity increased initially and then decreased. As the polymerization time increased, the conductivity first increased and then decreased. The increase in conductivity might be attributed to more polymer formation and uniform polymer deposition due to more time available, while the decrease at high polymerization time might be ascribed to the over-oxidation of the polymer 
leading to the deterioration of the electrical properties [60]. Similar observations were reported by Maiti et al. [61].

\subsubsection{Effect of Molar Ratio of $\mathrm{HCl}$ to Pyrrole and Polymerization Time on Conductivity}

The response surface plot for electrical conductivity of PPy/BC nanocomposites for the molar ratio of $\mathrm{HCl}$ to pyrrole ranging from 5 to 35 and polymerization time ranging from $60 \mathrm{~min}$ to $300 \mathrm{~min}$ against pyrrole amount of $0.30 \mathrm{~mL}$ is shown in Figure 4c. As expected, a similar trend of the molar ratio of $\mathrm{HCl}$ to pyrrole and polymerization time was observed here. The electrical conductivity initially increased and then decreased with the further increase in the molar ratio of $\mathrm{HCl}$ to pyrrole. As the polymerization time increased, the conductivity first increased and then decreased.

The optimal preparation process of PPy/BC nanocomposite by Design-Expert. 8.05b was as follows: the pyrrole amount was $0.32 \mathrm{~mL}$, the molar ratio of $\mathrm{HCl}$ to pyrrole was 20.94:1, polymerization time was $147.81 \mathrm{~min}$ and the predicted maximum conductivity was $7.21 \mathrm{~S} \mathrm{~cm}^{-1}$. In the actual operation process, the preparation parameters were simplified to $0.32 \mathrm{~mL}$ of pyrrole amount with a molar ratio of $\mathrm{HCl}$ to the pyrrole of (21:1) and a polymerization time of $150 \mathrm{~min}$. After three verification tests, the conductivity obtained was $(7.34 \pm 0.25) \mathrm{S} \mathrm{cm}^{-1}$, which was only $1.8 \%$ different from the predicted value, indicating that the regression model obtained by the response surface method was reliable and effective. Additionally, the electrical conductivity in this study was much higher than those of other PPy/cellulose fibers $\left(1.9 \times 10^{-2}-6.63 \mathrm{~S} \mathrm{~cm}^{-1}\right)$ [25]. Compared with the conductivities $1.14 \mathrm{~S} \mathrm{~cm}^{-1}$ for pure PPy [62], PPy/BC nanocomposites gave a 6-fold increase in conductivity, maybe due to better doping and more porous structures.

\subsection{Fourier Transform Infrared Spectroscopy}

Figure 5 presents the Fourier transform infrared (FT-IR) spectra of pure BC and PPy/BC membranes. The spectrum of pure BC membrane showed strong signals at $3334 \mathrm{~cm}^{-1}, 2884 \mathrm{~cm}^{-1}$ and $1017 \mathrm{~cm}^{-1}$ respectively. These signals corresponded to the characteristic absorption peak of $\mathrm{BC}$. The absorption peak at $3334 \mathrm{~cm}^{-1}$ was attributed to the intermolecular hydrogen bond stretching vibration caused by $\mathrm{O}-\mathrm{H}$ groups. The absorption peak at $2884 \mathrm{~cm}^{-1}$ was produced by asymmetrically stretching vibration of $\mathrm{C}-\mathrm{H}$ [63]. The peak at $1017 \mathrm{~cm}^{-1}$ was caused by the stretching vibration of $\mathrm{C}-\mathrm{O}$ bonds. Compared to $\mathrm{BC}$, a group of characteristic bands of PPy could be indexed in the PPy/BC composite, suggesting a successful polymerization [64]. The peaks at $1007 \mathrm{~cm}^{-1}, 1131 \mathrm{~cm}^{-1}$ and $1516 \mathrm{~cm}^{-1}$ were attributed to $\mathrm{C}-\mathrm{H}$ out-of-plane deformation vibration, $\mathrm{C}=\mathrm{C}$ and $\mathrm{C}-\mathrm{C}$ in-ring-stretching, respectively [19]. The $\mathrm{C}-\mathrm{N}$ stretching vibration peaks of PPy appeared at $1288 \mathrm{~cm}^{-1}$ and $1435 \mathrm{~cm}^{-1}$ [42].

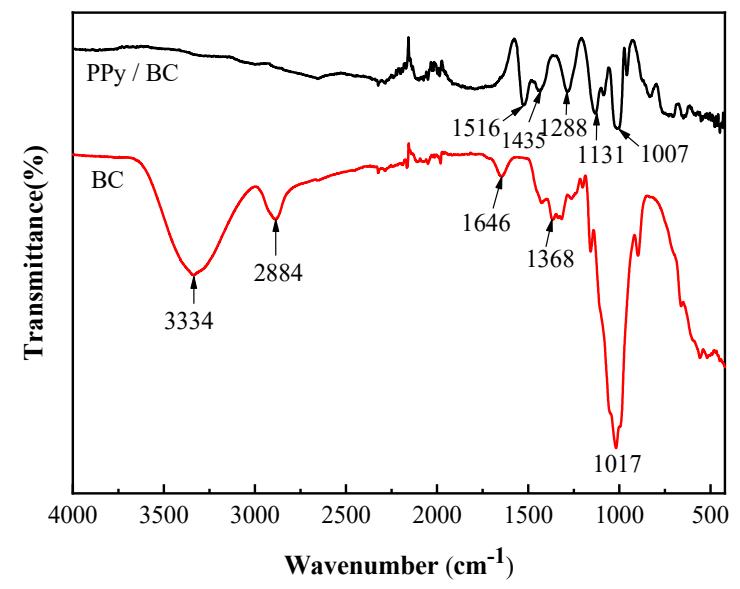

Figure 5. Fourier transform infrared (FT-IR) spectra of pure BC and PPy/BC membranes. 


\subsection{Thermal Stability Analysis}

The thermal stabilities of pure BC membrane and PPy/BC nanocomposite were investigated by thermogravimetric analysis (TGA) and derivative thermogravimetric (DTG) depicted in Figure 6. The pure $\mathrm{BC}$ membrane experienced mass losses were observed in three stages. From room temperature to $100{ }^{\circ} \mathrm{C}, 3.64 \%$ weight loss could be seen due to the hydration of water absorbed physically or bound by hydrogen bond on BC. The second weight loss at a higher temperature, which took place at $300^{\circ} \mathrm{C}$, was attributed to the decomposition of the amorphous $\mathrm{BC}$ region. The third stage at around $450{ }^{\circ} \mathrm{C}$ corresponded to the decomposition polymeric chains. For PPy/BC composite, the second stage of weight loss was a continuous process. The composite decomposed at a lower speed than pure cellulose. As shown in Figure $6 \mathrm{~b}$, at the second peak, the speed of weight loss shifted from $22.04 \% \mathrm{~min}^{-1}$ for cellulose to $2.32 \% \mathrm{~min}^{-1}$ for the composites. The PPy layer was the most external and more stable component that acted as a protective barrier against $\mathrm{BC}$ thermal degradation [18]. As a result, the composites exhibited higher thermal stability than pure cellulose. A similar result was obtained for PPy-coated silk fabrics [65], which was attributed to the interaction between cellulose and PPy.

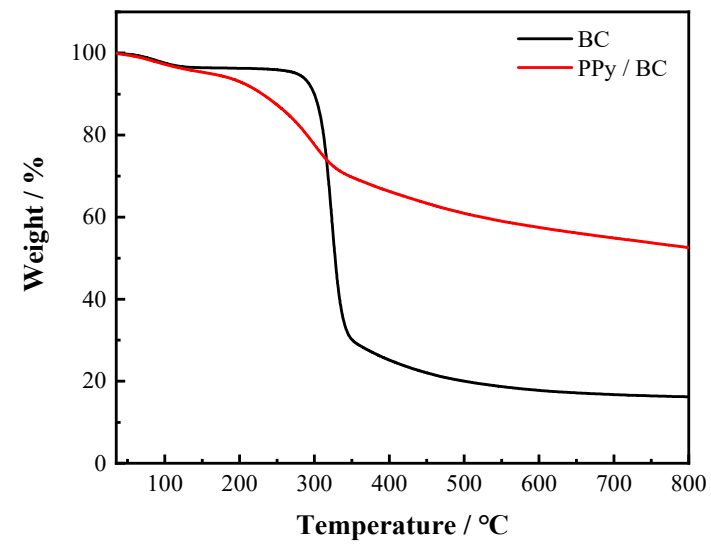

(a)

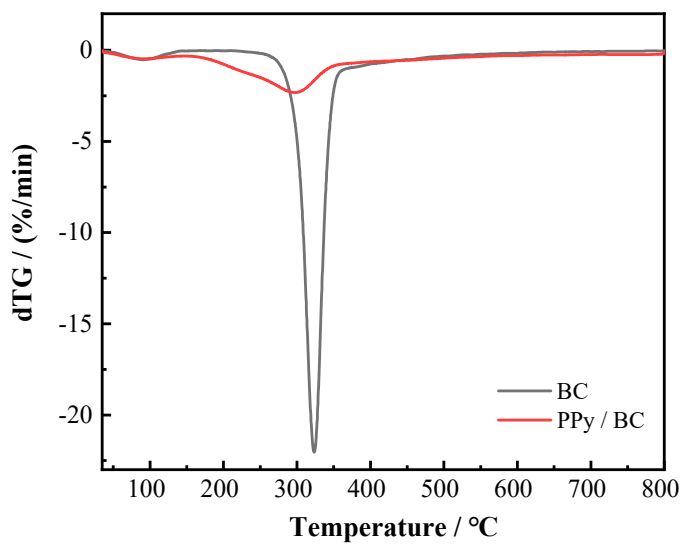

(b)

Figure 6. (a) Thermogravimetric analysis (TGA) and (b) derivative thermogravimetric (DTG) curves of pure $\mathrm{BC}$ and $\mathrm{PPy} / \mathrm{BC}$ nanocomposite.

\subsection{Electrochemical Performances}

In order to investigate the electrochemical performances of the PPy/BC nanocomposite prepared in optimal conditions, it was immersed in a $2.0 \mathrm{M} \mathrm{LiCl}$ electrolyte with a three-electrode configuration and explored by cyclic voltammetry (CV), galvanostatic charge-discharge (GCD), electrochemical impedance spectroscopy (EIS) measurements.

As shown in Figure 7a, the CV curves at different scan rates were nearly rectangular and basically symmetrical about the zero, demonstrating the ideal capacitive behavior. Moreover, as the scan rate increased, the shape of the curves was hardly changed. Figure $7 \mathrm{~b}$ presented the GCD curves at different current densities from 1 to $10 \mathrm{~mA} \mathrm{~cm}^{-2}$. They were nearly linear and symmetrical without an obvious $I R$ drop, suggesting a fast and good reversibility charge-discharge property of the electrode material [66]. At the discharge current density of $1 \mathrm{~mA} \mathrm{~cm}^{-2}$, the highest areal capacitance could reach 1001.26 $\mathrm{mF} \mathrm{cm}^{-2}$. This value was higher than that of PANI network/Au/paper electrode $\left(0.8 \mathrm{~F} \mathrm{~cm}^{-2}\right)$ [67], PANI@carbon and PPy@carbon (787.40 mF cm$~^{-2}$ and $\left.136.99 \mathrm{mF} \mathrm{cm}^{-2}\right)$ [68] and others $\left(0.4-30 \mathrm{mF} \mathrm{cm}^{-2}\right.$ ) reported in literature at the same discharge current density [69-72]. Simultaneously, it was found that the PPy/BC electrode retained about $90.97 \%$ of the initial capacitance after 80 cycles (Figure 7c). It should be pointed out that the cycling stability needed to be improved for practical applications. Figure $7 \mathrm{~d}$ showed the Nyquist plot of PPy/BC nanocomposite, which was made up of a semicircle at high-frequency region followed by a straight line at low-frequency region [43]. The diameter of the semicircle in the high to the midfrequency region represented the electron transfer resistance at the 
interface of the electrodes and electrolytes. The vertical line in the low-frequency region was caused by the charges stored in the electrochemical reaction. The slope of the line was indicative of the perfect capacitive behavior. It was found that the electrode had a low internal resistance, while the vertical line deviated from the imaginary axis indicating a slightly poor tantalum capacitance.

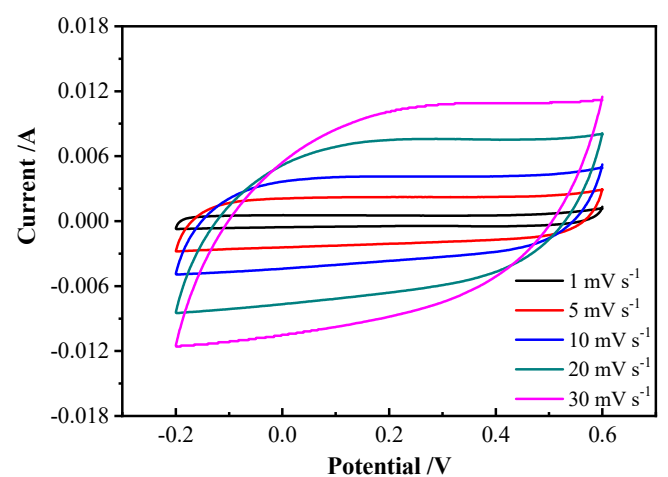

(a)

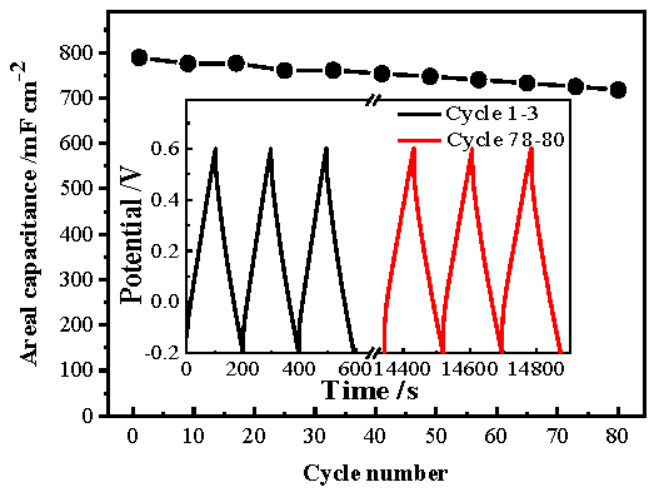

(c)

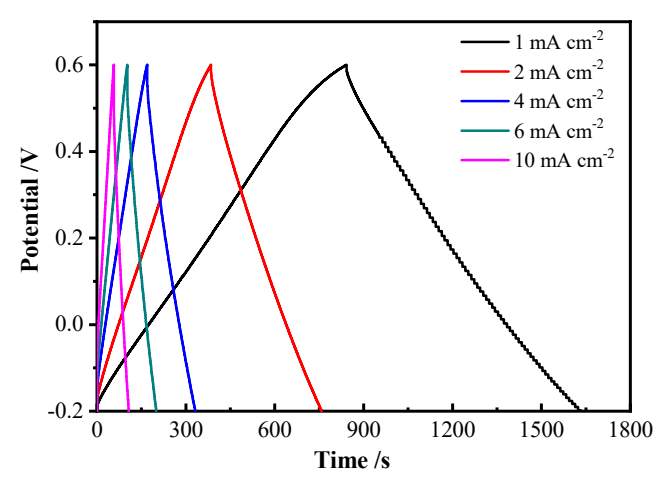

(b)

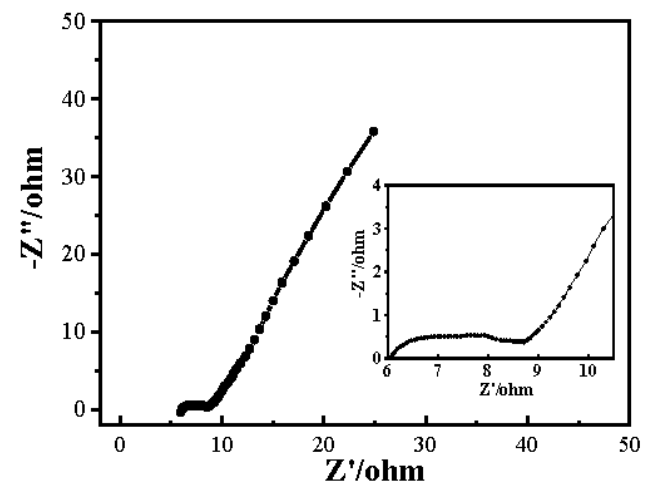

(d)

Figure 7. Electrochemical performances of PPy/BC nanocomposite prepared based on response surface: (a) cyclic voltammetry curves at different scan rates; (b) galvanostatic charge-discharge curves at different current densities; (c) cycle stability; (d) electrochemical impedance spectroscopy curves.

\section{Conclusions}

Based on the response surface methodology, a kind of flexible and conductive PPy/BC nanocomposite was successfully prepared by in situ chemical polymerization of pyrrole in the presence of BC. A maximum electrical conductivity of $7.21 \mathrm{~S} \mathrm{~cm}^{-1}$ was obtained by optimizing the process at a pyrrole amount of $0.32 \mathrm{~mL}$, the molar ratio of $\mathrm{HCl}$ to pyrrole of $(21: 1)$ and polymerization time of $150 \mathrm{~min}$. In the suggested optimal conditions, the experimentally determined response of $(7.34 \pm 0.25) \mathrm{S} \mathrm{cm}^{-1}$ was reasonably close to the predicted response. Moreover, the composite exhibited a high areal capacitance of $1001.26 \mathrm{mF} \mathrm{cm}^{-2}$ at the discharge current density of $1 \mathrm{~mA} \mathrm{~cm}^{-2}$, but its cycling stability could be further improved. The finding of this research demonstrates that RSM based on BBD is one of the most effective approaches for optimizing the conditions of synthesis. It also provides insight for the use of PPy/BC nanocomposites as flexible and conductive materials for intelligent and wearable textiles.

Author Contributions: Conceptualization, Y.C. and Z.L.; methodology, F.W.; software, X.H. and L.C.; validation, J.G., J.Z. and Q.L.; formal analysis, L.D.; investigation, L.D.; writing-original draft preparation, F.W.; writing-review and editing, Z.L. and Y.C.

Funding: This research was financially supported by the National Key Research and Development Project Foundation of China (2017YFB0309800, 2016YFC0400503-02), the Xinjiang Autonomous Region Major Significant Project Foundation(2016A03006-3), the Tianjin Natural Science Foundation (18JCYBJC89600), the Science and Technology Guidance Project of China National Textile and Apparel Council(2017011), the Science and Technology 
Plans of Tianjin (No. 17YFZCSF01230, 17PTSYJC00040 and 18PTSYJC00180), the Program for Innovative Research Team in University of Ministry of Education of China (No. IRT-17R80), the Program for Innovative Research Team in University of Tianjin (No. TD13-5044) and the 2018 Tianjin City-Level University Students Innovation and Entrepreneurship Training Project (No.201810058077).

Conflicts of Interest: The authors declare no conflict of interest.

\section{References}

1. Stoppa, M.; Chiolerio, A. Wearable Electronics and Smart Textiles: A Critical Review. Sensors 2014, 14, 11957-11992. [CrossRef] [PubMed]

2. Shim, B.S.; Chen, W.; Doty, C.; Xu, C.; Kotov, N.A. Smart Electronic Yarns and Wearable Fabrics for Human Biomonitoring made by Carbon Nanotube Coating with Polyelectrolytes. Nano Lett. 2008, 8, 4151-4157. [CrossRef]

3. Mukhopadhyay, S.C. Wearable Sensors for Human Activity Monitoring: A Review. IEEE Sens. J. 2015, 15, 1321-1330. [CrossRef]

4. Dhanabalan, S.C.; Dhanabalan, B.; Chen, X.; Ponraj, J.S.; Zhang, H. Hybrid carbon nanostructured fibers: Stepping stone for intelligent textile-based electronics. Nanoscale 2019, 11, 3046-3101. [CrossRef]

5. $\quad$ Liang, H.; Guan, Q.; Zhu, Z.; Song, L.; Yao, H.; Lei, X.; Yu, S. Highly conductive and stretchable conductors fabricated from bacterial cellulose. NPG Asia Mater. 2012, 4, e19. [CrossRef]

6. Snook, G.A.; Kao, P.; Best, A.S. Conducting-polymer-based supercapacitor devices and electrodes. J. Power Sources 2011, 196, 1-12. [CrossRef]

7. Ramya, R.; Sivasubramanian, R.; Sangaranarayanan, M.V. Conducting polymers-based electrochemical supercapacitors-Progress and prospects. Electrochim. Acta 2013, 101, 109-129. [CrossRef]

8. Xie, Y.; Zheng, Y.; Fan, J. Novel electronic-ionic hybrid conductive composites for multifunctional flexible bioelectrode based on in situ synthesis of polydopamine on bacterial cellulose. ACS Appl. Mater. Interfaces 2018, 10, 22692-22702. [CrossRef]

9. Yue, L.; Xie, Y.; Zheng, Y.; He, W.; Guo, S.; Sun, Y.; Zhang, T.; Liu, S. Sulfonated bacterial cellulose/polyaniline composite membrane for use as gel polymer electrolyte. Compos. Sci. Technol. 2017, 145, 122-131. [CrossRef]

10. Zhang, S.; Sun, G.; He, Y.; Fu, R.; Gu, Y.; Chen, S. Preparation, Characterization, and Electrochromic Properties of Nanocellulose-Based Polyaniline Nanocomposite Films. ACS Appl. Mater. Interfaces 2017, 9, 16426-16434. [CrossRef]

11. Liew, S.Y; Thielemans, W.; Walsh, D.A. Electrochemical Capacitance of Nanocomposite Polypyrrole/Cellulose Films. J. Phys. Chem. C 2010, 114, 17926-17933. [CrossRef]

12. Nystrom, G.; Razaq, A.; Stromme, M.; Nyholm, L.; Mihranyan, A. Ultrafast All-Polymer Paper-Based Batteries. Nano Lett. 2009, 9, 3635-3639. [CrossRef] [PubMed]

13. Malhotra, U.; Maity, S.; Chatterjee, A. Polypyrrole-silk electro-conductive composite fabric by in situ chemical polymerization. J. Appl. Polym. Sci. 2015, 132. [CrossRef]

14. Onar, N.; Akşit, A.C.; Ebeoglugil, M.F.; Birlik, I.; Celik, E.; Ozdemir, I. Structural, electrical, and electromagnetic properties of cotton fabrics coated with polyaniline and polypyrrole. J. Appl. Polym. Sci. 2009, 114, 2003-2010. [CrossRef]

15. Babu, K.F.; Senthilkumar, R.; Noel, M.; Kulandainathan, M.A. Polypyrrole microstructure deposited by chemical and electrochemical methods on cotton fabrics. Synth. Met. 2009, 159, 1353-1358. [CrossRef]

16. Molina, J.; Del Río, A.I.; Bonastre, J.; Cases, F. Electrochemical polymerisation of aniline on conducting textiles of polyester covered with polypyrrole/AQSA. Eur. Polym. J. 2009, 45, 1302-1315. [CrossRef]

17. Kaynak, A.; Najar, S.S.; Foitzik, R.C. Conducting nylon, cotton and wool yarns by continuous vapor polymerization of pyrrole. Synth. Met. 2008, 158, 1-5. [CrossRef]

18. Müller, D.; Rambo, C.R.; Recouvreux, D.O.S.; Porto, L.M.; Barra, G.M.O. Chemical in situ polymerization of polypyrrole on bacterial cellulose nanofibers. Synth. Met. 2011, 161, 106-111. [CrossRef]

19. Lay, M.G.I.T. High electrical and electrochemical properties in bacterial cellulose/polypyrrole membranes. Eur. Polym. J. 2017, 91, 1-9. [CrossRef]

20. Czaja, W.K.; Young, D.J.; Kawecki, M.; Brown, R.M., Jr. The future prospects of microbial cellulose in biomedical applications. Biomacromolecules 2007, 8, 1-12. [CrossRef] 
21. Hosseini, H.; Kokabi, M.; Mousavi, S.M. Conductive bacterial cellulose/multiwall carbon nanotubes nanocomposite aerogel as a potentially flexible lightweight strain sensor. Carbohydr. Polym. 2018, 201, 228-235. [CrossRef]

22. Ul-Islam, M.; Khan, T.; Park, J.K. Water holding and release properties of bacterial cellulose obtained by in situ and ex situ modification. Carbohydr. Polym. 2012, 88, 596-603. [CrossRef]

23. Choi, C.N.; Song, H.J.; Kim, M.J.; Chang, M.H.; Kim, S.J. Properties of bacterial cellulose produced in a pilot-scale spherical type bubble column bioreactor. Korean J. Chem. Eng. 2009, 26, 136-140. [CrossRef]

24. Li, H.X.; Kim, S.; Lee, Y.; Kee, C.D.; Oh, I.K. Determination of the stoichiometry and critical oxygen tension in the production culture of bacterial cellulose using saccharified food wastes. Korean J. Chem. Eng. 2011, 28, 2306-2311. [CrossRef]

25. Xu, J.; Zhu, L.; Bai, Z.; Liang, G.; Liu, L.; Fang, D.; Xu, W. Conductive polypyrrole-bacterial cellulose nanocomposite membranes as flexible supercapacitor electrode. Org. Electron. 2013, 14,3331-3338. [CrossRef]

26. Huanhuan Wang, L.B.P.Z. Core-Sheath structured bacterial cellulose/polypyrrole nanocomposites with excellent conductivity as supercapacitors. J. Mater. Chem. A 2013, 1, 578-584. [CrossRef]

27. Muller, D.; Rambo, C.R.; Porto, L.M.; Schreiner, W.H.; Barra, G.M.O. Structure and properties of polypyrrole/bacterial cellulose nanocomposites. Carbohydr. Polym. 2013, 94, 655-662. [CrossRef]

28. Tang, L.; Han, J.; Jiang, Z.; Chen, S.; Wang, H. Flexible conductive polypyrrole nanocomposite membranes based on bacterial cellulose with amphiphobicity. Carbohydr. Polym. 2015, 117, 230-235. [CrossRef]

29. Mengying, L.; Mufang, L.; Yuqin, L.; Kangqi, C.; Ke, L.; Qiongzhen, L.; Yuedan, W.; Zhentan, L.; Xue, L.; Dong, W. In-situ polymerization of PPy/cellulose composite sponge with high elasticity and conductivity for the application of pressure sensor. Compos. Commun. 2017, 6, 68-72. [CrossRef]

30. Hebeish, A.; Farag, S.; Sharaf, S.; Shaheen, T.I. Advancement in conductive cotton fabrics through in situ polymerization of polypyrrole-nanocellulose composites. Carbohydr. Polym. 2016, 151, 96-102. [CrossRef]

31. Babu, K.F.; Dhandapani, P.; Maruthamuthu, S.; Kulandainathan, M.A. One pot synthesis of polypyrrole silver nanocomposite on cotton fabrics for multifunctional property. Carbohydr. Polym. 2012, 90, 1557-1563. [CrossRef] [PubMed]

32. Jradi, K.; Bideau, B.; Chabot, B.; Daneault, C. Characterization of conductive composite films based on TEMPO-oxidized cellulose nanofibers and polypyrrole. J. Mater. Sci. 2012, 47, 3752-3762. [CrossRef]

33. Nystrom, G.; Mihranyan, A.; Razaq, A.; Lindstrom, T.; Nyholm, L.; Stromme, M. A Nanocellulose Polypyrrole Composite Based on Microfibrillated Cellulose from Wood. J. Phys. Chem. B 2010, 114, 4178-4182. [CrossRef] [PubMed]

34. Sharifi, H.; Zabihzadeh, S.M.; Ghorbani, M. The application of response surface methodology on the synthesis of conductive polyaniline/cellulosic fiber nanocomposites. Carbohydr. Polym. 2018, 194, 384-394. [CrossRef]

35. Parra-Campos, A.; Eduardo Ordonez-Santos, L. Natural pigment extraction optimization from coffee exocarp and its use as a natural dye in French meringue. Food Chem. 2019, 285, 59-66. [CrossRef]

36. Celik, F.; Aslani, M.A.A.; Can, S.S. Study of the Bioaccumulation of $\mathrm{UO}_{2}{ }^{2+}$ onto the Green Microalgae Botryococcus braunii Using Response Surface Methodology. Turk. J. Fish. Aquat. Sci. 2019, 19, 593-604. [CrossRef]

37. Wu, W.; He, L.; Liang, Y.; Yue, L.; Peng, W.; Jin, G.; Ma, M. Preparation process optimization of pig bone collagen peptide-calcium chelate using response surface methodology and its structural characterization and stability analysis. Food Chem. 2019, 284, 80-89. [CrossRef] [PubMed]

38. Meini, M.; Cabezudo, I.; Boschetti, C.E.; Romanini, D. Recovery of phenolic antioxidants from Syrah grape pomace through the optimization of an enzymatic extraction process. Food Chem. 2019, 283, 257-264. [CrossRef] [PubMed]

39. Monforte, A.R.; Oliveira, C.; Martins, S.I.F.S.; Silva Ferreira, A.C. Response surface methodology: A tool to minimize aldehydes formation and oxygen consumption in wine model system. Food Chem. 2019, 283, 559-565. [CrossRef]

40. Cervera, A.; Ezra, O.; Kuperman, A.; Peretz, M.M. Modeling and Control of Magnetic Actuation Systems Based on Sensorless Displacement Information. IEEE Trans. Ind. Electron. 2019, 66, 4849-4859. [CrossRef]

41. Silva Coelho, T.L.; Silva Braga, F.M.; Caldas Silva, N.M.; Dantas, C.; Lopes Junior, C.A.; Alves De Sousa, S.A.; Virira, E.C. Optimization of the protein extraction method of goat meat using factorial design and response surface methodology. Food Chem. 2019, 281, 63-70. [CrossRef] [PubMed] 
42. Li, S.; Huang, D.; Yang, J.; Zhang, B.; Zhang, X.; Yang, G.; Wang, M.; Shen, Y. Freestanding bacterial cellulose-polypyrrole nanofibres paper electrodes for advanced energy storage devices. Nano Energy 2014, 9 , 309-317. [CrossRef]

43. Luo, H.; Xiong, P.; Xie, J.; Yang, Z.; Huang, Y.; Hu, J.; Wan, Y.; Xu, Y. Uniformly Dispersed Freestanding Carbon Nanofiber/Graphene Electrodes Made by a Scalable Biological Method for High-Performance Flexible Supercapacitors. Adv. Funct. Mater. 2018, 28, 1803075. [CrossRef]

44. Bjorklund, R.B. Kinetics of pyrrole polymerisation in aqueous iron chloride solution. J. Chem. Soc. Faraday Trans. 1 Phys. Chem. Condens. Phases 1987, 83, 1507. [CrossRef]

45. Patil, B.H.; Bulakhe, R.N.; Lokhande, C.D. Supercapacitive performance of chemically synthesized polypyrrole thin films: Effect of monomer to oxidant ratio. J. Mater. Sci. Mater. Electron. 2014, 25, 2188-2198. [CrossRef]

46. Sabouraud, G.; Sadki, S.; Brodie, N. The mechanisms of pyrrole electropolymerization. Chem. Soc. Rev. 2000, 29, 283-293. [CrossRef]

47. Hu, W.; Chen, S.; Yang, Z.; Liu, L.; Wang, H. Flexible Electrically Conductive Nanocomposite Membrane Based on Bacterial Cellulose and Polyaniline. J. Phys. Chem. B 2011, 115, 8453-8457. [CrossRef] [PubMed]

48. Marins, J.A.; Soares, B.G.; Dahmouche, K.; Ribeiro, S.J.L.; Barud, H.; Bonemer, D. Structure and properties of conducting bacterial cellulose-polyaniline nanocomposites. Cellulose 2011, 18, 1285-1294. [CrossRef]

49. Keyvanloo, K.; Towfighi, J.; Sadrameli, S.M.; Mohamadalizadeh, A. Investigating the effect of key factors, their interactions and optimization of naphtha steam cracking by statistical design of experiments. J. Anal. Appl. Pyrol. 2010, 87, 224-230. [CrossRef]

50. Mondal, S.K.; Saha, A.K.; Sinha, A. Removal of ciprofloxacin using modified advanced oxidation processes: Kinetics, pathways and process optimization. J. Clean. Prod. 2018, 171, 1203-1214. [CrossRef]

51. Khataee, A.R.; Zarei, M.; Moradkhannejhad, L. Application of response surface methodology for optimization of azo dye removal by oxalate catalyzed photo electro-Fenton process using carbon nanotube-PTFE cathode. Desalination 2010, 258, 112-119. [CrossRef]

52. Kasiri, M.B.; Aleboyeh, H.; Aleboyeh, A. Modeling and Optimization of Heterogeneous Photo-Fenton Process with Response Surface Methodology and Artificial Neural Networks. Environ. Sci. Technol. 2008, 42, 7970-7975. [CrossRef] [PubMed]

53. Derakhshan, M.; Fazeli, M. Improved biodegradability of hardly-decomposable wastewaters from petrochemical industry through photo-Fenton method and determination of optimum operational conditions by response surface methodology. J. Biol. Eng. 2018, 12. [CrossRef] [PubMed]

54. Shen, Y.; Xu, Q.; Gao, D.; Shi, H. Degradation of an Anthraquinone Dye by Ozone/Fenton: Response Surface Approach and Degradation Pathway. Ozone Sci. Eng. 2017, 39, 219-232. [CrossRef]

55. Satapathy, M.K.; Das, P. Optimization of crystal violet dye removal using novel soil-silver nanocomposite as nanoadsorbent using response surface methodology. J. Environ. Chem. Eng. 2014, 2, 708-714. [CrossRef]

56. Amini, M.; Younesi, H.; Bahramifar, N.; Lorestani, A.A.Z.; Ghorbani, F.; Daneshi, A.; Sharifzadeh, M. Application of response surface methodology for optimization of lead biosorption in an aqueous solution by Aspergillus niger. J. Hazard. Mater. 2008, 154, 694-702. [CrossRef]

57. Hamsaveni, D.R.; Prapulla, S.G.; Divakar, S. Response surface methodological approach for the synthesis of isobutyl isobutyrate. Process Biochem. 2001, 36, 1103-1109. [CrossRef]

58. Ding, C.; Qian, X.; Yu, G.; An, X. Dopant effect and characterization of polypyrrole-cellulose composites prepared by in situ polymerization process. Cellulose 2010, 17, 1067-1077. [CrossRef]

59. Razak, S.I.A.; Rahman, W.A.W.A.; Sharif, N.F.A.; Yahya, M.Y. Simultaneous numerical optimization of the mechanical and electrical properties of polyaniline coated kenaf fiber using response surface methodology: Nanostructured polyaniline on natural fiber. Compos. Interface 2012, 19, 411-424. [CrossRef]

60. Maity, S.; Chatterjee, A. Preparation and characterization of electro-conductive rotor yarn by in situ chemical polymerization of pyrrole. Fiber. Polym. 2013, 14, 1407-1413. [CrossRef]

61. Maiti, S.; Das, D.; Sen, K. Studies on Electro-Conductive Yarns Prepared by In Situ Chemical and Electrochemical Polymerization of Pyrrole. J. Appl. Polym. Sci. 2012, 123, 455-462. [CrossRef]

62. Wang, D.; Li, Y.; Shi, Z.; Qin, H.; Wang, L.; Pei, X.; Jin, J. Spontaneous Growth of Free-Standing Polypyrrole Films at an Air/Ionic Liquid Interface. Langmuir 2010, 26, 14405-14408. [CrossRef] [PubMed]

63. Yuan, L.; Yao, B.; Hu, B.; Huo, K.; Chen, W.; Zhou, J. Polypyrrole-coated paper for flexible solid-state energy storage. Energy Environ. Sci. 2013, 6, 470-476. [CrossRef] 
64. Bose, S.; Kim, N.H.; Kuila, T.; Lau, K.; Lee, J.H. Electrochemical performance of a graphene-polypyrrole nanocomposite as a supercapacitor electrode. Nanotechnology 2011, 22. [CrossRef]

65. Cucchi, I.; Boschi, A.; Arosio, C.; Bertini, F.; Freddi, G.; Catellani, M. Bio-based conductive composites: Preparation and properties of polypyrrole (PPy)-coated silk fabrics. Synth. Met. 2009, 159, $246-253$. [CrossRef]

66. Kaempgen, M.; Chan, C.K.; Ma, J.; Cui, Y.; Gruner, G. Printable Thin Film Supercapacitors Using Single-Walled Carbon Nanotubes. Nano Lett. 2009, 9, 1872-1876. [CrossRef]

67. Yuan, L.; Xiao, X.; Ding, T.; Zhong, J.; Zhang, X.; Shen, Y.; Hu, B.; Huang, Y.; Zhou, J.; Wang, Z.L. Paper-Based Supercapacitors for Self-Powered Nanosystems. Angew. Chem. Int. Ed. 2012, 51, 4934-4938. [CrossRef] [PubMed]

68. Liu, T.; Finn, L.; Yu, M.; Wang, H.; Zhai, T.; Lu, X.; Tong, Y.; Li, Y. Polyaniline and Polypyrrole Pseudocapacitor Electrodes with Excellent Cycling Stability. Nano Lett. 2014, 14, 2522-2527. [CrossRef] [PubMed]

69. Bae, J.; Song, M.K.; Park, Y.J.; Kim, J.M.; Liu, M.; Wang, Z.L. Fiber Supercapacitors Made of Nanowire-Fiber Hybrid Structures for Wearable/Flexible Energy Storage. Angew. Chem. Int. Ed. 2011, 50, 1683-1687. [CrossRef] [PubMed]

70. In, H.J.; Kumar, S.; Shao-Horn, Y.; Barbastathis, G. Origami fabrication of nanostructured, three-dimensional devices: Electrochemical capacitors with carbon electrodes. Appl. Phys. Lett. 2006, 88. [CrossRef]

71. Stilwell, D.E.; Su-Moon, P. Electrochemistry of conductive polymers. II. Electrochemical studies on growth properties of polyaniline. J. Electrochem. Soc. 1988, 135, 2254-2262. [CrossRef]

72. Meng, C.; Liu, C.; Chen, L.; Hu, C.; Fan, S. Highly Flexible and All-Solid-State Paper like Polymer Supercapacitors. Nano Lett. 2010, 10, 4025-4031. [CrossRef] [PubMed]

(C) 2019 by the authors. Licensee MDPI, Basel, Switzerland. This article is an open access article distributed under the terms and conditions of the Creative Commons Attribution (CC BY) license (http://creativecommons.org/licenses/by/4.0/). 